\title{
Epidemiology of canine visceral leishmaniasis in a vulnerable region in Brazil
}

\author{
Soroepidemiologia da leishmaniose visceral canina em uma região vulnerável \\ do Brasil
}
Douglas Aparecido da Silva'; Natália Camila Minucci Bonatto²; Gabriela Lovizutto Venturin³; Larissa Martins Melo3; Paula Lima de Oliveira3,4; Letícia Ramos Costa4; Maria Rachel Melo Bosculo4; Luiz Daniel de Barros; Valéria Marçal Felix de Lima3; Breno Fernando Martins de Almeida ${ }^{3,4^{*}}$ (D)
${ }^{1}$ Laboratório de Protozoologia Animal, Departamento de Medicina Veterinária Preventiva, Universidade Estadual de Londrina -UEL, Londrina, PR, Brasil
${ }^{2}$ Laboratório Clínico Veterinário, Departamento de Medicina Veterinária Preventiva, Universidade Estadual de Londrina - UEL, Londrina, PR, Brasil
${ }^{3}$ Laboratório de Imunologia, Departamento de Clínica, Cirurgia e Reprodução Animal, Universidade Estadual Paulista - UNESP Campus Araçatuba, Araçatuba, SP, Brasil
${ }^{4}$ Hospital Veterinário Roque Quagliato, Departamento de Medicina Veterinária, Centro Universitário das Faculdades Integradas de Ourinhos - Unifio, Ourinhos, SP, Brasil

How to cite: Silva DA, Bonatto NCM, Venturin GL, Melo LM, Oliveira PL, Costa LR, et al. Epidemiology of canine visceral leishmaniasis in a vulnerable region in Brazil. Braz J Vet Parasito/ 2021; 30(3): e009921. https://doi.org/10.1590/S1984-29612021075

\begin{abstract}
Visceral leishmaniasis (VL) is a neglected and endemic zoonosis that occurs throughout Brazil; nevertheless, few studies have focused on the early detection of the disease. The municipality of Ourinhos is a non-receptive, silent and vulnerable area for $\mathrm{VL}$, where the seroprevalence of this disease has so far not been investigated. The present study aimed to determine the seroprevalence of canine VL in Ourinhos-SP, and to identify the presence of risk factors. Blood samples were obtained from 604 dogs during a rabies vaccination campaign together with application of a socioeconomic questionnaire, environmental and animal characteristics and tutor's knowledge about the disease. The samples were subjected to indirect ELISA and new samples were collected from reactive and suspect animals, including whole blood and lymph node aspiration evaluated by parasitological method, complete blood count and PCR. No animal was diagnosed as positive based on the combination of direct and indirect tests and the tutors' answers indicated little knowledge about leishmaniasis, being often confused with other diseases transmitted by arthropods; hence, according to the proposed methods, the presence of canine leishmaniasis in the city of Ourinhos was not confirmed and health education campaigns about the disease should be carried out.
\end{abstract}

Keywords: Leishmania spp., dog, indirect ELISA.

\section{Resumo}

A leishmaniose visceral (LV) é uma zoonose negligenciada e endêmica presente em todas as regiões do Brasil, mas mesmo assim poucos estudos têm objetivado a deteç̧ão inicial da doença. O município de Ourinhos - SP é uma área não receptiva, silenciosa e vulnerável à LV, não havendo até o momento estudos que tenham investigado a soroprevalência no município. Nesse sentido, o presente estudo objetivou determinar a soroprevalência da LV canina em Ourinhos-SP, bem como associar a presença de fatores de risco. Amostras sanguíneas de 604 cães foram obtidas juntamente com a aplicação de questionário socioeconômico, características ambientais e dos animais e conhecimento sobre a doença. As amostras foram submetidas à sorologia por ELISA e novas amostras coletadas de cães reagentes ou suspeitos foram analisadas por método parasitológico direto, hemograma e PCR. Nenhum animal foi considerado positivo na combinação de testes direto e indireto, e as respostas dos tutores indicaram pouco conhecimento sobre a leishmaniose, sendo muitas vezes confundida com outras doenças 
transmitidas por artrópodes. Dessa forma, de acordo com os métodos propostos, a presença de leishmaniose canina, na cidade de Ourinhos, não foi confirmada. Por isso, campanhas de educação em saúde sobre a doença deveriam ser realizadas.

Palavras-chave: Leishmania spp., cães, ELISA indireto.

\section{Introduction}

Visceral Leishmaniasis (VL) is a zoonotic disease caused by protozoa of the genus Leishmania and transmitted by sandflies such as Lutzomyia longipalpis, which is considered the main vector in Brazil (Brasil, 2019). The disease is classified as a neglected tropical disease, and according to the World Health Organization (WHO), it is one of the six most important infectious diseases worldwide, ranking as the second parasitic disease that causes the most deaths in the world. About 350 million people live in endemic areas and are at risk of infection. In the Americas, $\mathrm{VL}$ is an important public health problem from Mexico to Argentina (WHO, 2016).

In the state of São Paulo, 8,553 cases of human VL were reported in 107 municipalities between 1999 and 2019 (Rangel et al., 2020). Previous studies have demonstrated that the presence of the vector and canine infection precede human cases, justifying the need for identification of the vector and infected dogs (Brasil, 2019; Rangel et al., 2020).

In domestic dogs - the main reservoir host of the parasite in the urban cycle, the disease is considered multisystemic, causing different clinical signs such as cutaneous lesions, keratoconjunctivitis, cachexia, onychogryphosis and enlarged lymph nodes. In the chronic phase, liver and splenomegaly and kidney disease are commonly observed (Marcondes \& Rossi, 2014; Almeida et al., 2017a, b). The most common hematological abnormalities include normocytic and normochromic non-regenerative anemia, leukocytosis, neutropenia, lymphocytosis and thrombocytopenia. Signs of kidney injuries may be present in chronic stages due to the deposition of immune complexes (Ikeda-Garcia et al., 2003). Although a medication for the treatment of canine VL has recently been approved in Brazil, the federal agencies still recommend euthanasia as a way of controlling the disease (Brasil, 2019). Direct and indirect methods can be used for the diagnosis of canine infection; however, serology has been used for screening, while DNA detection and microscopy are commonly used to confirm the infection (Brasil, 2019), since serological tests may cross-react with other pathogens (Zanette et al., 2014; Lopes et al., 2017).

Ourinhos is a city located in the interior of the state of São Paulo, classified as silent, non-receptive and vulnerable according to the Paulista Epidemiologic Bulletin, due to the lack of autochthonous transmission, absence of sandflies and proximity to endemic cities such as Bauru and Marília, respectively (Rangel et al., 2020). Furthermore, to date, no studies have evaluated autochthonous transmission in both humans and dogs in the city. Due to the importance of public health and the rapid expansion in the country, serological surveys are essential to prevent the expansion and increase in the incidence of the disease. Thus, this study aimed to evaluate the epidemiology of canine visceral leishmaniasis in Ourinhos and to determine its association with risk factors.

\section{Material and Methods}

\section{Ethics statement}

All the procedures involving animals and their owners were approved by the Ethics Committee of the Centro Universitário das Faculdades Integradas de Ourinhos (no. 26/2017) and the Research Ethics Committee of the Faculdade de Medicina de Marília (no. 2.584.911). Dogs were included in the study only after obtaining their owners' consent.

\section{Study area and sampling}

The study was conducted in Ourinhos ( $22^{\circ} 58^{\prime} 59^{\prime \prime} \mathrm{S}, 49^{\circ} 51^{\prime} 25^{\prime \prime}$ W), a municipality of $295,818 \mathrm{~km}^{2}$ in the state of São Paulo, with a population of 113,542.

The initial sample size of 530 animals was calculated using Epilnfo v.7 software, considering a population of 15,000 dogs according to the Municipal Health Department, an estimated prevalence of $50 \%$, and a confidence level of 95\%. Dogs were sampled in September and October 2017 during the municipal vaccination campaign against rabies at 25 vaccination stations distributed across the city. Blood collection from at least 10 dogs was carried out at each vaccination station, being randomly collected by sampling in 1 out of 10 dogs that were vaccinated 
and had more than 6 months of age. The blood samples $(2 \mathrm{~mL})$ were obtained by cephalic puncture, placed in a tube containing clot activator (BD Vacutainer ${ }^{\circledR}$, Becton-Dickson, New Jersey, USA) and centrifuged, and serum was stored at $-20^{\circ} \mathrm{C}$ until the serological analysis. After blood sampling, a questionnaire about tutor's socioeconomic information, characteristics of the animal and its residence, and tutor's knowledge about VL was made available for completion by the tutor. Afterwards, each tutor received a brief explanation about VL and how to prevent it.

Approximately three months after the first blood collection (December 2017), 10 of these dogs that were suspected of having VL or were reactive by iELISA, underwent a physical examination and new blood samples and popliteal lymph node material was collected by aspiration for complete blood count, PCR and direct parasitological analysis. Other two dogs, one suspected (sample A-14) and other reactive (sample K-16) for canine VL, had no samples recolected because one of them died (K-16) and the other was missing at the time of resampling (A-16), so parasitological direct examination was not performed and PCR reactions of these samples were conducted from serum samples of the first sampling period.

\section{Enzyme-linked immunosorbent assay (ELISA) and immunochromatographic test}

iELISA was performed using the total antigen of Leishmania infantum, as previously described (Lima et al., 2003). Dogs were considered reactive when the optical density (OD) was greater than 0.270 and were considered suspect when the OD was between 0.198 and 0.269 as previously reported (Lima et al., 2003).

The serum samples from dogs reactive and suspected $(n=12)$ of CVL were also subjected to the Dual Path Platform (DPP) Canine Visceral Leishmaniasis serological test (Biomanguinhos/FioCruz, Rio de Janeiro, Brazil).

\section{Complete blood count}

Complete blood counts (CBC) and total plasma protein (TPP) concentration were performed in a veterinary hematology analyzer (HORIBA ABX Micros ESV 60, Paris, France) and using a portable clinical refractometer (ATAGO, Mod. Master-SUR-NM, Tokyo, Japan), respectively, following previous recommendations (Jain, 1986; Costa et al., 2020; Oliveira et al., 2020).

\section{Direct parasitological examination}

Part of the material obtained by aspiration biopsy of popliteal lymph node from reactive and suspected dogs $(n=10)$ was smeared onto microscope slides, and stained with commercial hematological dye (Panótico Rápido, Laborclin, Pinhais, PR, Brazil). The slides were examined under an optical microscope at 1000x magnification for at least $30 \mathrm{~min}$, to detect amastigote forms of Leishmania spp.

\section{Diagnosis of other infectious agents and PCR}

A serological and molecular diagnosis of the main infectious diseases that could interfere in serological tests for canine leishmaniasis by iELISA (Zanette et al., 2014) was also performed. This included serological tests for canine monocytic ehrlichiosis (CME), anaplasmosis, borreliosis and heartworm disease (SNAP 4DX Plus Test ${ }^{\circledR}$, IDEXX Laboratories, USA) and molecular diagnosis of babesiosis, CME, neosporosis, toxoplasmosis, trypanosomiasis, and other common infection agents observed in our veterinary routine such as anaplamosis and hepatozoonosis according to PCR protocols described on Tables 1 and 2 .

Samples destined for PCR reaction consisted of the remaining popliteal lymph node aspirates which was homogenized with $100 \mu \mathrm{L}$ of sterile $\mathrm{NaCl} 0.9 \%$ solution and pooled with $100 \mu \mathrm{L}$ of blood from the same dog from the dogs from which new samples $(n=10)$ were collected, and serum from the dogs from which new samples could not be collected $(n=2)$. The sample was then subjected to DNA extraction using a commercial kit (Norgen Biotek Corp, Canada), following the manufacturer's instructions. The DNA sample was eluted in $50 \mu \mathrm{L}$, and stored at $-20^{\circ} \mathrm{C}$ until the moment of PCR processing.

Prior to the molecular detection, all the DNA samples were subjected to a PCR test targeting the housekeeping gene G3PDH, following a previously described method (Peters et al., 2007).

Nested PCR was used to detect Leishmania spp. DNA according to an earlier modified protocol (Albuquerque et al., 2017). To elicit a secondary Leishmania spp. reaction, the product of the first reaction was diluted 1:200. All the 
Table 1. Reaction target, description and concentration of primers, product size and references used in polymerase chain reaction (PCR) for the detection of infectious agents and housekeeping genes.

\begin{tabular}{|c|c|c|c|c|}
\hline Target & Primers & $\begin{array}{c}\text { Primer } \\
\text { concentration }\end{array}$ & $\begin{array}{l}\text { Product size } \\
(\mathrm{pb})\end{array}$ & Reference \\
\hline G3PDH & $\begin{array}{l}\text { FW: 5' TCAACGGATTTTGGCCCGTATTTGG 3' } \\
\text { RV: 5' TGAAGGGGGTCATTGATGGCG 3' }\end{array}$ & $0.2 \mu \mathrm{M}$ & 90 & Peters et al. (2007) \\
\hline $\begin{array}{c}\text { Primary } \\
\text { Leishmania spp. }\end{array}$ & $\begin{array}{c}\text { FW: 5' GGTTCCTTTCCTGATTTACG 3' } \\
\text { RV: 5' GGCCGGTAAACGTAAAGGCCGAATAG 3' }\end{array}$ & $15 \mathrm{pM}$ & 603 & \multirow{2}{*}{$\begin{array}{l}\text { Albuquerque et al. } \\
\text { (2017) }\end{array}$} \\
\hline $\begin{array}{c}\text { Secondary } \\
\text { Leishmania spp. }\end{array}$ & $\begin{array}{l}\text { FW: 5' TCCATCGCAACCTCGGTT 3' } \\
\text { RV: 5' AAAGCGGGCGCGGTGCTG 3' }\end{array}$ & $15 \mathrm{pM}$ & 358 & \\
\hline $\begin{array}{c}\text { Primary } \\
\text { Anaplasma platys }\end{array}$ & $\begin{array}{l}\text { FW: 5' AGAGTTTGATCCTGGCTCAG 3' } \\
\text { RV: 5' TAGCACTCATCGTTTACAGC 3' }\end{array}$ & $12.5 \mathrm{pM}$ & 760 & \multirow{2}{*}{ Inokuma et al. (2001) } \\
\hline $\begin{array}{c}\text { Secondary } \\
\text { Anaplasma platys }\end{array}$ & $\begin{array}{l}\text { FW: 5' AAGTCGAACGGATTTTTTGTC 3' } \\
\text { RV: 5' CTTTAACTTACCGAACC 3' }\end{array}$ & $12.5 \mathrm{pM}$ & 466 & \\
\hline Babesia canis & $\begin{array}{l}\text { FW: 5' CCGTGCTAATTGTAGGGCTAATACA 3' } \\
\text { RV: 5' GCTTGAAACACTCTARTTTCTCAAAG 3' }\end{array}$ & $0.2 \mathrm{mM}$ & 551 & $\begin{array}{l}\text { Spolidorio et al. } \\
\text { (2011) }\end{array}$ \\
\hline Ehrlichia canis & $\begin{array}{l}\text { FW: 5' CCTCTGGCTATAGGAAATTG 3' } \\
\text { RV: 5' GGAGTGCTTAACGCGTTAG 3' }\end{array}$ & $50 \mathrm{pM}$ & 761 & Alves et al. (2006) \\
\hline Hepatozoon canis & $\begin{array}{c}\text { FW: 5' CGCGAAATTACCCAATTCTA 3' } \\
\text { RV: 5' TAAGGTGCTGAAGGAGTCGTTTAT 3' }\end{array}$ & $0.2 \mu \mathrm{M}$ & 670 & Spolidorio et al. (2009) \\
\hline Neospora caninum & $\begin{array}{l}\text { FW: 5' GGGTGTGCGTCCAATCCTGTAAC 3' } \\
\text { RV: 5' CTCGCCAGTCAAACCTACGTCTTCT 5' }\end{array}$ & $10 \mathrm{pM}$ & 337 & Liddell et al. (1999) \\
\hline Toxoplasma gondii & $\begin{array}{l}\text { FW: 5' GGAACTGCATCCGTTCATGAG 3' } \\
\text { RV: 5' TCTTTAAAGCGTTCGTGGTC 3' }\end{array}$ & $50 \mathrm{pM}$ & 194 & Spalding et al. (2002) \\
\hline Trypanossoma cruzi & $\begin{array}{l}\text { FW: 5' AAATAATGTACGGGGGAGATGCATGA 3' } \\
\text { RV: 5' GGGTTCGATTGGGGTTGGTGT 3' }\end{array}$ & 300 pM & 330 & Avila et al. (1990) \\
\hline $\begin{array}{l}\text { Trypanosoma } \\
\text { evansi }\end{array}$ & $\begin{array}{l}\text { FW: 5' AAACCCGTCCTCTTGGAGG 3' } \\
\text { RV: 5' ATCCATCTAAGAGTTGT 3' }\end{array}$ & $200 \mathrm{pM}$ & 315 & $\begin{array}{l}\text { Ventura et } \\
\text { al. (2002) }\end{array}$ \\
\hline
\end{tabular}

Table 2. Polymerase chain reaction (PCR) conditions for the detection of infectious agents and housekeeping genes.

\begin{tabular}{|c|c|c|c|c|c|c|}
\hline Target & $\begin{array}{c}\text { Initial } \\
\text { activation }\end{array}$ & Denaturation & Annealing & Extension & Cycles & Final extension \\
\hline G3PDH & $94^{\circ} \mathrm{C} 5 \mathrm{~min}$ & $95^{\circ} \mathrm{C} 30 \mathrm{~s}$ & $60^{\circ} \mathrm{C} 30 \mathrm{~s}$ & $72^{\circ} \mathrm{C} 30 \mathrm{~s}$ & 35 & $72^{\circ} \mathrm{C} 7 \mathrm{~min}$ \\
\hline $\begin{array}{c}\text { Primary } \\
\text { Leishmania spp. }\end{array}$ & $94^{\circ} \mathrm{C} 5 \mathrm{~min}$ & $94^{\circ} \mathrm{C} 30 \mathrm{~s}$ & $60^{\circ} \mathrm{C} 30 \mathrm{~s}$ & $72^{\circ} \mathrm{C} 30 \mathrm{~s}$ & 35 & $72^{\circ} \mathrm{C} 7 \mathrm{~min}$ \\
\hline $\begin{array}{c}\text { Secondary } \\
\text { Leishmania spp. }\end{array}$ & $94^{\circ} \mathrm{C} 5 \mathrm{~min}$ & $94^{\circ} \mathrm{C} 30 \mathrm{~s}$ & $65^{\circ} \mathrm{C} 30 \mathrm{~s}$ & $72^{\circ} \mathrm{C} 30 \mathrm{~s}$ & 35 & $72^{\circ} \mathrm{C} 7 \mathrm{~min}$ \\
\hline $\begin{array}{c}\text { Primary } \\
\text { Anaplasma platys }\end{array}$ & $94^{\circ} \mathrm{C} 5 \mathrm{~min}$ & $94^{\circ} \mathrm{C} 60 \mathrm{~s}$ & $55^{\circ} \mathrm{C} 60 \mathrm{~s}$ & $72^{\circ} \mathrm{C} 60 \mathrm{~s}$ & 35 & $72^{\circ} \mathrm{C} 5 \mathrm{~min}$ \\
\hline $\begin{array}{c}\text { Secondary } \\
\text { Anaplasma platys }\end{array}$ & $94^{\circ} \mathrm{C} 5 \mathrm{~min}$ & $94^{\circ} \mathrm{C} 60 \mathrm{~s}$ & $55^{\circ} \mathrm{C} 60 \mathrm{~s}$ & $72^{\circ} \mathrm{C} 60 \mathrm{~s}$ & 35 & $72^{\circ} \mathrm{C} 5 \mathrm{~min}$ \\
\hline $\begin{array}{l}\text { Babesia } \\
\text { canis }\end{array}$ & $94^{\circ} \mathrm{C} 5 \mathrm{~min}$ & $95^{\circ} \mathrm{C} 60 \mathrm{~s}$ & $64^{\circ} \mathrm{C} 30 \mathrm{~s}$ & $72^{\circ} \mathrm{C} 30 \mathrm{~s}$ & 35 & $72^{\circ} \mathrm{C} 7 \mathrm{~min}$ \\
\hline $\begin{array}{l}\text { Ehrlichia } \\
\text { canis }\end{array}$ & $94^{\circ} \mathrm{C} 5 \mathrm{~min}$ & $94^{\circ} \mathrm{C} 60 \mathrm{~s}$ & $54^{\circ} \mathrm{C} 60 \mathrm{~s}$ & $72^{\circ} \mathrm{C} 60 \mathrm{~s}$ & 40 & $72^{\circ} \mathrm{C} 7 \mathrm{~min}$ \\
\hline $\begin{array}{l}\text { Hepatozoon } \\
\text { canis }\end{array}$ & $94^{\circ} \mathrm{C} 5 \min$ & $95^{\circ} \mathrm{C} 15 \mathrm{~s}$ & $53^{\circ} \mathrm{C} 40 \mathrm{~s}$ & $72^{\circ} \mathrm{C} 40 \mathrm{~s}$ & 40 & $72^{\circ} \mathrm{C} 5 \mathrm{~min}$ \\
\hline $\begin{array}{l}\text { Toxoplasma } \\
\text { gondii }\end{array}$ & $94^{\circ} \mathrm{C} 5 \mathrm{~min}$ & $94^{\circ} \mathrm{C} 60 \mathrm{~s}$ & $55^{\circ} \mathrm{C} 45 \mathrm{~s}$ & $72^{\circ} \mathrm{C} 60 \mathrm{~s}$ & 35 & $72^{\circ} \mathrm{C} 7 \mathrm{~min}$ \\
\hline $\begin{array}{l}\text { Neospora } \\
\text { caninum }\end{array}$ & $94^{\circ} \mathrm{C} 5 \mathrm{~min}$ & $94^{\circ} \mathrm{C} 40 \mathrm{~s}$ & $63^{\circ} \mathrm{C} 40 \mathrm{~s}$ & $72^{\circ} \mathrm{C} 60 \mathrm{~s}$ & 40 & $72^{\circ} \mathrm{C} 10 \mathrm{~min}$ \\
\hline $\begin{array}{c}\text { Trypanossoma } \\
\text { cruzi }\end{array}$ & $94^{\circ} \mathrm{C} 5$ min & $94^{\circ} \mathrm{C} 60 \mathrm{~s}$ & $65^{\circ} \mathrm{C} 60 \mathrm{~s}$ & $72^{\circ} \mathrm{C} 60 \mathrm{~s}$ & 30 & $72^{\circ} \mathrm{C} 10 \mathrm{~min}$ \\
\hline $\begin{array}{l}\text { Trypanosoma } \\
\text { evansi }\end{array}$ & $94^{\circ} \mathrm{C} 5$ min & $95^{\circ} \mathrm{C} 60 \mathrm{~s}$ & $56^{\circ} \mathrm{C} 120 \mathrm{~s}$ & $72^{\circ} \mathrm{C} 120 \mathrm{~s}$ & 30 & $72^{\circ} \mathrm{C} 5 \mathrm{~min}$ \\
\hline
\end{tabular}


reactions were performed using 1x MasterMix Red (Ampliqon, Denmark), $1 \cup$ Taq DNA polymerase, and primers in a final volume of $50 \mu \mathrm{L}$ (Tables 1 and 2).

The PCR products were subjected to electrophoresis on 3\% agarose gel (LE Agarose 1200, NeoTaq) with ethidium bromide 0.05\% (Sigma Aldrich, USA), examined and photographed under UV light (MiniBis ProBio Imaging Systems). Molecular weight LowRanger 100pb DNA Ladder (Norgen Biotek Corp., Canada) was added to all the agarose gels, and ultrapure distilled water (RNA and DNAase free water, Gibco-Invitrogen, USA) was used as negative control in all the reactions, each of which had a positive control.

\section{Results}

Blood samples were collected from 604 dogs, but only 557 dog owners filled out the questionnaire completely, so that was the number of samples considered in the study. Of these, $54 \%$ came from males and $46 \%$ from females. There was a predominance of mixed breed dogs, i.e., $69 \%$, followed by poodles (4.4\%), labrador retrievers and pit bulls (4\%), bassets (3\%), Ihasa apsos and rottweilers (2.25\%) and doberman pinscher (2\%), border collies and Brazilian terriers (1\%), while other breeds corresponded to less than $1 \%$ of the dogs. As for their ages, 81 dogs were 6 months to 1 year old, 185 ranged from 1 to 3 years, 247 from 3 to 10 years, and 51 were older 10 years. The owners of 13 dogs did not know their age.

Table 3. Results of diagnostic methods for the detection of canine visceral leishmaniasis, including iELISA serology, Dual Path Platform (DPP) immunochromatographic serology, direct parasitological method from popliteal lymph node aspirate and polymerase chain reaction (PCR) to amplify the variable part of the small subunit rRNA gene of Leishmania spp., samples A-14 and K-16 had PCR reaction performed from serum of the first sampling.

\begin{tabular}{|c|c|c|c|c|}
\hline Sample code & $\begin{array}{l}\text { OD } \\
\text { iELISA }\end{array}$ & DPP & $\begin{array}{c}\text { Direct parasitological } \\
\text { examination }\end{array}$ & PCR \\
\hline A-14 & 0.259 / Suspect & Non-reactive & Not performed & Negative \\
\hline $\mathrm{J}-07$ & 0.285 / Reactive & Reactive & Negative & Negative \\
\hline $\mathrm{J}-08$ & $0.411 /$ Reactive & Non-reactive & Negative & Negative \\
\hline$J-31$ & 0.307 / Reactive & Reactive & Negative & Negative \\
\hline $\mathrm{K}-16$ & 0.298 / Reactive & Non-reactive & Not performed & Negative \\
\hline $\mathrm{N}-10$ & 0.227 / Suspect & Non-reactive & Negative & Negative \\
\hline $0-05$ & 0.372 / Reactive & Reactive & Negative & Negative \\
\hline O-08 & 0.240 / Suspect & Non-reactive & Negative & Negative \\
\hline $0-19$ & 0.257 / Suspect & Non-reactive & Negative & Negative \\
\hline Q-24 & 0.198 / Suspect & Non-reactive & Negative & Negative \\
\hline V-05 & 0.218 / Suspect & Non-reactive & Negative & Negative \\
\hline V-06 & $0.350 /$ Reactive & Non-reactive & Negative & Negative \\
\hline
\end{tabular}

Dogs were considered reactive when the optical density (OD) was greater than 0.270 and were considered suspect when the OD was between 0.198 and 0.269 .

Of the total of 577 samples analyzed by ELISA, 6 whose OD was higher than 0.270 were considered reactive, and 6 whose OD ranged from 0.198 and 0.259 were considered suspected. These samples were also subjected to the DPP serological test for Canine Visceral Leishmaniasis, and three were considered reactive (Table 3).

Blood samples could not be collected a second time from two of the dogs, because one of them died of a cause unknown to the owner (sample K-16) and the other was missing at the time of resampling (sample A-14). None of the reassessed dogs $(n=10)$ presented amastigote forms of Leishmania spp. by direct parasitological examination of samples of blood smears and popliteal lymph node aspirates (Table 3), although all the lymph node samples contained sufficient material for cytological evaluation and PCR reaction. 
All the samples ( $n=12$ ) amplified G3PDH gene, which was used as DNA extraction control, including the serum sample from the two dogs (samples A-14 and K-16) from which blood samples could not be collected for a second time. All the dogs presented negative nested PCR to amplify the variable part of the small subunit rRNA gene of Leishmania spp. three months after the initial serological test (Table 3). When the presence of DNA from other infectious agents was identified by PCR analyses, one sample tested positive for Anaplasma platys, Babesia canis vogeli, Ehrlichia canis and Hepatozoon canis; two were positive for A. platys, B. canis vogeli and $H$. canis; two were positive for $B$. canis vogeli, E. canis and $H$. canis; one was positive for $B$. canis vogeli and E. canis; two for E. canis and H. canis; and two only for $\mathrm{H}$. canis. None of the samples tested positive for Neospora caninum, Toxoplasma gondii,

Table 4. Results of polymerase chain reaction (PCR) and serology results on 4DX Plus for the detection of other infectious agents.

\begin{tabular}{|c|c|c|c|c|c|c|c|c|c|c|c|c|}
\hline \multirow{2}{*}{$\begin{array}{c}\text { Sample } \\
\text { code }\end{array}$} & \multicolumn{8}{|c|}{ PCR } & \multicolumn{4}{|c|}{ 4DX Plus } \\
\hline & $\begin{array}{c}\text { A. } \\
\text { platys }\end{array}$ & $\begin{array}{l}\text { B. } \\
\text { canis }\end{array}$ & $\begin{array}{c}E . \\
\text { canis }\end{array}$ & $\begin{array}{c}\text { H. } \\
\text { canis }\end{array}$ & $\begin{array}{c}N . \\
\text { caninum }\end{array}$ & $\begin{array}{c}T . \\
\text { gondii }\end{array}$ & $\begin{array}{c}T . \\
\text { cruzi }\end{array}$ & $\begin{array}{c}T . \\
\text { evansi }\end{array}$ & E. canis & A. platys & $\begin{array}{c}\text { B. } \\
\text { burgdorferi }\end{array}$ & $\begin{array}{c}\text { D. } \\
\text { immitis }\end{array}$ \\
\hline A-14 & - & - & - & - & - & - & - & - & Reactive & $\begin{array}{l}\text { Non- } \\
\text { reactive }\end{array}$ & $\begin{array}{l}\text { Non- } \\
\text { reactive }\end{array}$ & $\begin{array}{l}\text { Non- } \\
\text { reactive }\end{array}$ \\
\hline $\mathrm{J}-07$ & - & + & + & - & - & - & - & - & Reactive & $\begin{array}{l}\text { Non- } \\
\text { reactive }\end{array}$ & $\begin{array}{l}\text { Non- } \\
\text { reactive }\end{array}$ & $\begin{array}{l}\text { Non- } \\
\text { reactive }\end{array}$ \\
\hline $\mathrm{J}-08$ & + & + & - & + & - & - & - & - & Reactive & Reactive & $\begin{array}{l}\text { Non- } \\
\text { reactive }\end{array}$ & $\begin{array}{l}\text { Non- } \\
\text { reactive }\end{array}$ \\
\hline $\mathrm{J}-31$ & - & + & + & + & - & - & - & - & Reactive & $\begin{array}{l}\text { Non- } \\
\text { reactive }\end{array}$ & $\begin{array}{l}\text { Non- } \\
\text { reactive }\end{array}$ & $\begin{array}{l}\text { Non- } \\
\text { reactive }\end{array}$ \\
\hline $\mathrm{K}-16$ & - & - & - & + & - & - & - & - & Reactive & $\begin{array}{l}\text { Non- } \\
\text { reactive }\end{array}$ & $\begin{array}{l}\text { Non- } \\
\text { reactive }\end{array}$ & $\begin{array}{l}\text { Non- } \\
\text { reactive }\end{array}$ \\
\hline $\mathrm{N}-10$ & - & + & + & + & - & - & - & - & Reactive & $\begin{array}{l}\text { Non- } \\
\text { reactive }\end{array}$ & $\begin{array}{l}\text { Non- } \\
\text { reactive }\end{array}$ & $\begin{array}{l}\text { Non- } \\
\text { reactive }\end{array}$ \\
\hline $0-05$ & + & + & + & + & - & - & - & - & Reactive & Reactive & $\begin{array}{l}\text { Non- } \\
\text { reactive }\end{array}$ & $\begin{array}{l}\text { Non- } \\
\text { reactive }\end{array}$ \\
\hline $0-08$ & + & + & - & + & - & - & - & - & Reactive & Reactive & $\begin{array}{l}\text { Non- } \\
\text { reactive }\end{array}$ & $\begin{array}{l}\text { Non- } \\
\text { reactive }\end{array}$ \\
\hline O-19 & - & - & + & + & - & - & - & - & Reactive & $\begin{array}{l}\text { Non- } \\
\text { reactive }\end{array}$ & $\begin{array}{l}\text { Non- } \\
\text { reactive }\end{array}$ & $\begin{array}{l}\text { Non- } \\
\text { reactive }\end{array}$ \\
\hline Q-24 & - & - & + & + & - & - & - & - & Reactive & $\begin{array}{l}\text { Non- } \\
\text { reactive }\end{array}$ & $\begin{array}{l}\text { Non- } \\
\text { reactive }\end{array}$ & $\begin{array}{l}\text { Non- } \\
\text { reactive }\end{array}$ \\
\hline V-05 & - & - & - & + & - & - & - & - & Reactive & Reactive & $\begin{array}{l}\text { Non- } \\
\text { reactive }\end{array}$ & $\begin{array}{l}\text { Non- } \\
\text { reactive }\end{array}$ \\
\hline V-06 & - & - & - & + & - & - & - & - & Reactive & Reactive & $\begin{array}{l}\text { Non- } \\
\text { reactive }\end{array}$ & $\begin{array}{l}\text { Non- } \\
\text { reactive }\end{array}$ \\
\hline
\end{tabular}

+: pathogen DNA detection on PCR; -: absence of pathogen DNA on PCR.

Trypanosoma cruzi or Trypanosoma evansi (Table 4). The immunochromatographic serological tests for other infectious agents also detected that all the samples $(n=12)$ contained anti-E. canis antibodies and five of them also presented anti-A. platys antibodies (Table 4).

The clinical reassessment of the dogs $(n=10)$ revealed that $70 \%$ of them had ectoparasites, and all of them presented one or more clinical signs. The main signs were emaciation (60\%), ulcerative skin lesions (60\%), alopecia $(40 \%)$, lymphadenomegaly (30\%), mucopurulent eye discharge and hyperkeratosis (20\%), and onychogryphosis (10\%). The CBC indicated that these dogs suffered predominantly from hyperproteinemia with the presence of rouleaux formation (70\%), thrombocytopenia (70\%) and normochromic normocytic anemia (60\%) (Table 5).

The questionnaire applied to dog owners revealed that $56 \%$ of them were aware of $\mathrm{VL}, 31 \%$ learned about it from TV, 22\% from pamphlets, 19\% from the Internet, and the rest cited two or more other sources. More than 
Table 5. Physical findings and complete blood count of dogs reactive to and suspected of canine leishmaniasis, from which a second sample was collected $(n=10)$.

\begin{tabular}{|c|c|c|c|c|}
\hline \multicolumn{5}{|c|}{ Physical findings } \\
\hline \multicolumn{2}{|c|}{ Presence of ectoparasites } & & \multicolumn{2}{|l|}{$70 \%$} \\
\hline \multicolumn{2}{|c|}{ Emaciation } & & \multicolumn{2}{|l|}{$60 \%$} \\
\hline \multicolumn{2}{|c|}{ Ulcerative skin lesions } & & \multicolumn{2}{|l|}{$60 \%$} \\
\hline \multicolumn{2}{|c|}{ Alopecia } & & \multicolumn{2}{|l|}{$40 \%$} \\
\hline \multicolumn{2}{|c|}{ Lymphadenomegaly } & & \multicolumn{2}{|l|}{$30 \%$} \\
\hline \multicolumn{2}{|c|}{ Hyperkeratosis } & & \multicolumn{2}{|l|}{$20 \%$} \\
\hline \multicolumn{2}{|c|}{ Eye discharge } & & \multicolumn{2}{|l|}{$20 \%$} \\
\hline \multicolumn{2}{|c|}{ Onychogryphosis } & & \multicolumn{2}{|l|}{$10 \%$} \\
\hline \multicolumn{5}{|c|}{ Complete blood count findings } \\
\hline Parameter & Decreased (\%) & Normal (\%) & & Increased (\%) \\
\hline Hematocrit & 60 & 40 & & 0 \\
\hline Platelet count & 70 & 30 & & 0 \\
\hline Total white blood cell count & 30 & 60 & & 10 \\
\hline Segmented neutrophil count & 10 & 80 & & 10 \\
\hline Lymphocite count & 20 & 70 & & 10 \\
\hline Monocyte count & 0 & 100 & & 0 \\
\hline Eosinophil count & 10 & 80 & & 10 \\
\hline Total plasma protein & 0 & 30 & & 70 \\
\hline
\end{tabular}

$80 \%$ stated that the source of transmission is a mosquito, $14 \%$ reported the tick as a vector, $3 \%$ stated bites, and $1 \%$ believed transmission was caused by blood from other animals, from rats, or did not know. The common names of sandflies such as "mosquito-palha" and "birigui" were recognized by $57 \%$ of the participants, 35\% knew about them exclusively from TV, 20\% from pamphlets, and 15\% from the Internet. Almost $70 \%$ of respondents did not know about any preventive measures against the spread of VL. When questioned about disease control measures, $48 \%$ believed that euthanasia is a valid method, $29 \%$ cited castration, while $17 \%$ and $6 \%$, respectively, cited screening windows and preventing standing water or keeping backyards clean.

Considering the main risk factors for VL, most of the interviewees lived in houses with backyard (61\%), 38\% had lawns or flower beds, and $1 \%$ lived in houses without a backyard. Grassy areas in the neighborhood were reported by $80 \%$. Other green areas such as parks and gardens in the vicinity were reported by $81 \%$. The presence of chicken coops in the neighborhood was reported by $15 \%$ of participants and $5 \%$ had their own chicken coop. The presence of other animals in the home environment was reported by $41 \%$ of dog owners, most of them being cats (62\%) and some type of bird (34\%). In addition, $24 \%$ of them lived in locations where there were farms animals in the surrounding area, and $34 \%$ of them were next-door neighbors of farms with farms animals.

As for preventive measures against $\mathrm{VL}$, more than $90 \%$ of respondents stated that their dogs do not wear insect repellent collars and $60 \%$ of owners do not take their dogs to the veterinarian on a regular basis. Of the 577 animals, $20 \%$ were neutered and $38 \%$ were vaccinated only against rabies. With regard to how the owners acquired their dogs, $25 \%$ acquired their dog as an adult, $20 \%$ took them in off the street, and $40 \%$ adopted them from someone they know who lives in another location. Sixty percent of owners stated they regularly walk their dogs on different days and times. The majority (66\%) of the animals have access to an open yard, but $43 \%$ sleep in an open yard without shelter. Short coats were predominant (75\%), and $4 \%$ of dog owners took their dogs on trips. 


\section{Discussion}

Of the 577 samples analyzed, six were reactive and six were considered suspect by iELISA for canine visceral leishmaniasis, as proposed by Lima et al. (2003). Of these samples, three were also serologically positive by DPP, a rapid screening test recommended by the Brazilian public health authorities for the diagnosis of canine leishmaniasis. However, three months after the initial serological test, none of the dogs presented amastigote forms of Leishmania spp. by the direct parasitological methods or Leishmania spp. DNA amplification by PCR, which are methods whose detection sensitivity ranges from 74 to $97 \%$ (Assis et al., 2010).

Our diagnostic investigation continued, particularly because the clinical signs presented by the dogs were also suggestive of canine leishmaniasis. Some of the dogs were emaciated and/or had ulcerative lesions, alopecia and lymphadenomegaly, which are clinical signs frequently observed in dogs with leishmaniasis (Marcondes \& Rossi, 2014; Almeida et al., 2017a, b). Moreover, ectoparasites were detected on $70 \%$ of these animals. The abnormalities detected in the $\mathrm{CBC}$ included normocytic anemia, thrombocytopenia and hyperproteinemia, which also led us to consider the possibility of cross-reactivity in the serological test for canine leishmaniasis. Cesar (2008) evaluated the occurrence of ehrlichiosis in dogs with symptomatology compatible with the disease and confirmed the presence of E. canis DNA in 27 of 86 tested animals, all of which showed clinical signs such as lymphadenomegaly, splenomegaly and ocular lesions similar to those detected in the dogs of our study. Lymphadenomegaly, followed by anemia and thrombocytopenia, were the main clinical and laboratory findings in dogs with monocytic ehrlichiosis, corroborating the PCR results reported by Nakaghi et al. (2008). Borin et al. (2009) conducted a study involving 4407 dogs from a Veterinary Hospital, where E. canis morulae was detected in the blood smears of 251 dogs and 48 animals showed coinfection with babesiosis. Common clinical signs exhibited by these animals were apathy, anorexia, eye discharge, splenomegaly and anemia, most of which are clinical signs that can also occur in dogs with VL. The clinical signs of canine leishmaniasis may vary according to the time of infection and the host's immune response. That is why the signs are often nonspecific and can lead to mistaken diagnoses of other infectious and parasitic diseases, making it difficult to confirm a positive case based only on one diagnostic test (Marcondes \& Rossi, 2014).

Zanette et al. (2014) evaluated serological cross-reactivity upon testing for canine leishmaniasis using the same methodology as that used in our study. They identified dogs with toxoplasmosis $(n=10)$, ehrlichiosis $(n=13)$, babesiosis $(n=12)$, trypanosomiasis (by $T$. cruzi, $n=14$ ) and neosporosis $(n=8), 42.1 \%$ of which tested positive by one of the three serological methods for the diagnosis of canine leishmaniasis: 10/57 (17.5\%) in the iELISA with total crude antigen, 11/57 (19.3\%) in the indirect immunofluorescence test and 3/57 (5.3\%) in the immunochromatographic test (Kalazar Detect ${ }^{\mathrm{TM}}$ ). The above mentioned authors considered only dogs with trypanosomiasis and ehrlichiosis in the iELISA, with $64 \%$ and $7.6 \%$, respectively, showing cross-reactivity. Given that canine monocytic ehrlichiosis is the most frequent infectious disease in our veterinary hospital care (unpublished data) and that $1.03 \%$ of all the collected samples were reactive in the iELISA for canine leishmaniasis, this percentage is still well below the possibility of cross-reactivity with ehrlichiosis reported by the authors. This is particularly relevant when considering that all dogs were reactive to serologic testing for ehrlichiosis by immunochromatographic test. Parasites of the genus Leishmania spp. belong to the family Trypanosomatidae, which explains the finding of high cross-reactivity with Trypanosoma spp. infection in several studies (Mendes et al., 2013; Matos et al., 2015). Costa \& Vieira (2001) showed that $83.3 \%$ of the samples they subjected to serological tests showed cross-reactivity between Leishmania spp. and $T$. cruzi. However, none of the dogs tested in our study presented amplification of $T$. cruzi DNA in the pooled sample of blood and popliteal lymph node, leading us to assume that cross-reactivity occurs predominantly with ehrlichiosis.

In this context, several other studies have also demonstrated the cross-reactivity of other infectious diseases in serological tests for canine visceral leishmaniasis. Ferreira et al. (2007) applied indirect immunofluorescence and ELISA and observed cross-reactivity with canine leishmaniasis in dogs infected with T. cruzi, L. braziliensis and $E$. canis. A study involving 353 dogs carried out in the state of Bahia by Deiró et al. (2018) compared the occurrence of anti-E. canis antibodies, Leishmania spp. and T. gondii. These authors reported that coinfection of Leishmania spp. and $T$. gondii occurred in $7.1 \%$ of the cases, Leishmania spp. and E. canis in $5.7 \%$, and that $4.5 \%$ of the dogs were coinfected with the three agents. These levels of infection are higher than those found in our study. Considering our results, we reiterate what has been discussed about the sensitivity of the different diagnostic methods for the diagnosis of canine VL (Lopes et al., 2017; Vaz et al., 2020). No test currently available has 100\% specificity and sensitivity. This fact leads us to call into question the effectiveness of serological surveys used as screening for control of the disease by euthanizing serum reactive animals, a long-standing guideline of Brazilian government agencies (Alves \& Bevilacqua, 2004; Gontijo \& Melo, 2004; Assis et al., 2010). Some authors have suggested using a 
combination of diagnostic tests, particularly of direct and indirect detection methods to confirm the infection, since results may differ as a function of the test, sample, disease evolution and immune response of the host (Gontijo \& Melo, 2004; Queiroz et al., 2010; Sousa, 2012; Marcondes \& Rossi, 2014).

In our evaluation of the population's understanding of VL in the municipality of Ourinhos, more than half of the interviewees stated they had no knowledge about the disease, and among those who stated they knew about leishmaniasis, many associated it with dengue fever. When asked where they saw or heard about the disease, the main means of information the research participants listed was TV, followed by pamphlets and the Internet. Most of them reported they had heard about it on TV newscasts, and many stated that the name "mosquito-palha" brought to mind the disease. In response to a questionnaire applied by Lobo et al. (2013) to 743 students in a public school to assess their knowledge about VL, 203 stated that the disease is transmitted by a vector and 197 said that the vector of transmission was the Aedes aegypti mosquito. In our study, A. aegypti was mostly also considered a vector of transmission, but as stated earlier herein, the disease was often mistaken for dengue, making it difficult to outline a real parameter about the population's understanding in this regard. Among the prevention methods, practically all the answers described the elimination of standing water, further reinforcing the mistaken idea of dengue fever.

We observed that most of the dogs in the municipality have free access to the street and do not wear any type of insect repellent collar, important risks factors for canine VL pointed by other studies. Studies evaluating the use of insect repellent collars to prevent $V L$ in dogs have shown that this method is highly effective in controlling the disease. Moreover, dogs without such collars pose a risk factor for the occurrence of disease, since these collars act directly to reduce the number of vectors, of infected dogs, and thus also of human cases of the disease, including children, among whom lethality rates are higher (Mazloumi Gavgani et al., 2002; Sevá et al., 2016). However, the implementation of dog collar programs is still difficult due to the costs, loss of collars, adoption by the government, geographic diversity and adequate planning according to the reality of each region (Morais et al., 2015; Sevá et al., 2016; Bersusa et al., 2018). Leal et al. (2018) demonstrated that the incidence of leishmaniasis-positive dogs decreased by $61 \%$ in a period of 6 to 12 months, using deltamethrin-impregnated collars. With regard to the environment, more than $80 \%$ of the participants live in houses with backyard lawns or in neighborhoods with green areas. These are places where the odds of detecting ticks, mosquitoes and sandflies are higher, which could be considered risk factors for visceral leishmaniasis, according to Costa et al. (2015) and Menezes et al. (2016).

Most of the interviewees believe that neutering and euthanasia are ways to control the disease. This may be due to the fact that some of the interviewees relate the disease with how the canine population was historically controlled, which involved catching dogs on the street, or solving the problem of stray dogs by using these methods.

Taken together, the owners' responses to the questionnaires reveal that there are many risk factors for the occurrence of VL in the municipality of Ourinhos, SP, including dog handling practices, environmental conditions and proximity to endemic sites (Prado et al., 2011; Costa et al., 2015). A comparison of the results of studies conducted in both endemic locations and municipalities without confirmed cases revealed that Ourinhos presented factors in common with both of them. These factors include the paucity of dogs wearing collars, the fact that the majority of short-haired dogs spend most of their time outdoors in their owners' yards or in neighborhoods with green areas, the presence of production animals in the vicinity, and the population's lack of knowledge about the disease (Coiro et al., 2011; Menezes et al., 2016; Leal et al., 2018; Leite et al., 2018). This combination of factors underscores the municipality's vulnerability to the emergence of VL cases.

In this regard, alternatives to control the dissemination of the disease are extremely important, such as early diagnosis in dogs, which would help reduce human cases of VL if the disease began to be detected. Another important alternative is the population's health education and active surveillance of animals and the environment (Coura-Vital et al., 2014; Carvalho et al., 2018).

Although the municipality of Ourinhos is considered silent, non-receptive and vulnerable to canine leishmaniasis, we can state that there is evidence supporting the notion of the transmission of autochthonous cases should the disease and its vector arrive in the municipality, given the presence of numerous risk factors. It is also evident that the population lacks information about VL control, revealing that health education should be intensified.

\section{Conclusions}

The seroepidemiological diagnosis of canine visceral leishmaniasis in the municipality of Ourinhos enabled the detection of serum reactive dogs, but confirmation of the infection by other diagnostic methods revealed that 
cross-reactivity may have resulted in false positive cases. Moreover, the population's knowledge about the disease and prevention methods must be improved.

\section{Acknowledgements}

The authors gratefully acknowledge the financial support of FAPESP (São Paulo Research Foundation) (Process No. 2018/00184-8), and the technical support provided by the Municipal Health Department of Ourinhos and by Carlos César Boschetti.

\section{References}

Albuquerque A, Campino L, Cardoso L, Cortes S. Evaluation of four molecular methods to detect Leishmania infection in dogs. Parasit Vectors 2017; 10(1): 57. http://dx.doi.org/10.1186/s13071-017-2002-2. PMid:28285595.

Almeida BFM, Silva KLO, Chiku VM, Leal AAC, Venturin GL, Narciso LG, et al. The effects of increased heme oxygenase-1 on the lymphoproliferative response in dogs with visceral leishmaniasis. Immunobiology 2017a; 222(5): 693-703. http://dx.doi. org/10.1016/j.imbio.2016.12.006. PMid:28065450.

Almeida BFM, Silva KLO, Venturin GL, Chiku VM, Leal AAC, Bosco AM, et al. Induction of haem oxygenase-1 increases infection of dog macrophages by L. infantum. Parasite Immuno/ 2017b; 39(12): e12494. http://dx.doi.org/10.1111/pim.12494. PMid:28929503.

Alves LM, Linhares GFC, Chaves NST, Monteiro LC, Linhares DCL. Avaliação de iniciadores e protocolo para o diagnóstico da pancitopenia tropical canina por PCR. Cienc Anim Bras 2006; 6(1): 49-54.

Alves WA, Bevilacqua PD. Reflexões sobre a qualidade do diagnóstico da leishmaniose visceral canina em inquéritos epidemiológicos: o caso da epidemia de Belo Horizonte, Minas Gerais, Brasil, 1993-1997. Cad Saude Publica 2004; 20(1): 259-265. http://dx.doi.org/10.1590/S0102-311X2004000100043. PMid:15029328.

Assis J, Queiroz NMGP, Silveira RCV, Nunes CM, Oliveira TMFS, Noronha ACF Jr, et al. Estudo comparativo dos métodos diagnósticos para Leishmaniose Visceral em cães oriundos de Ilha Solteira, SP. Rev Bras Parasitol Vet 2010; 19(1): 17-25. http:// dx.doi.org/10.1590/S1984-29612010000100005. PMid:20385055.

Avila H, Goncalves AM, Nehme NS, Morel CM, Simpson L. Schizodeme analysis of Trypanosoma cruzi stocks from South and Central America by analysis of PCR-amplified minicircle variable region sequences. Mol Biochem Parasitol 1990; 42(2): 175-187. http://dx.doi.org/10.1016/0166-6851(90)90160-N. PMid:2270100.

Bersusa AAS, Toma TS, Araujo BC, Melo RC, Henriques LF. Coleira impregnada com deltametrina para cães na prevenção da transmissão de leishmaniose visceral por flebotomíneos: um parecer técnico-cietífico. São Paulo: Instituto de Saúde; 2018. http:// dx.doi.org/10.13140/rg.2.2.36279.16804.

Borin S, Crivelenti LZ, Ferreira FA. Aspectos epidemiológicos, clínicos e hematológicos de 251 cães portadores de mórula de Ehrlichia spp. naturalmente infectados. Arq Bras Med Vet Zootec 2009; 61(3): 566-571. http://dx.doi.org/10.1590/S010209352009000300007

Brasil. Ministério da Saúde. Secretaria de Vigilância em Saúde. Leishmaniose visceral. In: Brasil. Ministério da Saúde. Secretaria de Vigilância em Saúde. Guia de Vigilância em Saúde. 3. ed. Brasília: Ministério da Saúde; 2019. p. 503-22.

Carvalho AG, Luz JGG, Rodrigues LD, Dias JVL, Fontes CJF. High seroprevalence and peripheral spatial distribution of visceral leishmaniasis among domestic dogs in an emerging urban focus in Central Brazil: a cross-sectional study. Pathog Glob Health 2018; 112(1): 29-36. http://dx.doi.org/10.1080/20477724.2018.1438229. PMid:29460695.

Cesar MFG. Ocorrência de Ehrlichia canis em cães sintomáticos atendidos no hospital veterinário da Universidade de Brasília e análise de variabilidade em regiões genômicas de repetição [dissertação]. Brasília: Universidade de Brasília; 2008.

Coiro CJ, Langoni H, Silva RC, Ullmann LS. Fatores de risco para leptospirose, leishmaniose, neosporose e toxoplasmose em cães domiciliados e peridomíciliados em Botucatu-SP. Vet Zootec 2011; 18(3): 393-407.

Costa AP, Costa FB, Soares HS, Ramirez DG, Araújo AC, Silva Ferreira JIG, et al. Environmental factors and ecosystems associated with canine visceral leishmaniasis in Northeastern Brazil. Vector Borne Zoonotic Dis 2015; 15(12): 765-774. http://dx.doi.org/10.1089/ vbz.2015.1866. PMid:26684524.

Costa CHN, Vieira JBF. Mudanças no controle da leishmaniose visceral no Brasil. Rev Soc Bras Med Trop 2001; 34(2): 223-228. http://dx.doi.org/10.1590/S0037-86822001000200013. PMid:11391448.

Costa LR, Silva NLT, Oliveira PL, Bonatto NCM, Vieira GC, Floriano BP, et al. Diurnal variations in canine hematological parameters after commercial feed feeding. Semina: Ciênc Agrár 2020; 41(Suppl 1): 2219-2230. http://dx.doi.org/10.5433/16790359.2020v41n5supl1p2219. 
Coura-Vital W, Ker HG, Roatt BM, Aguiar-Soares RDO, Leal GGA, Moreira ND, et al. Evaluation of change in canine diagnosis protocol adopted by the visceral leishmaniasis control program in Brazil and a new proposal for diagnosis. PLoS One 2014; 9(3): e91009. http://dx.doi.org/10.1371/journal.pone.0091009. PMid:24608904.

Deiró AGJ, Montargil SMA, Carvalho FS, Munhoz AD, Albuquerque GR. Antibody occurrence of Anti-Toxoplasma gondii, Leishmania sp. and Ehrlichia canis in dogs in Bahia State. Semina: Ciênc Agrár 2018; 39(1): 199-210. http://dx.doi.org/10.5433/16790359.2018v39n1p199.

Ferreira EC, de Lana M, Carneiro M, Reis AB, Paes DV, da Silva ES, et al. Comparison of serological assays for the diagnosis of canine visceral leishmaniasis in animals presenting different clinical manifestations. Vet Parasito/ 2007; 146(3-4): 235-241. http:// dx.doi.org/10.1016/j.vetpar.2007.02.015. PMid:17403582.

Gavgani AS, Hodjati MH, Mohite H, Davies CR. Effect of insecticide-impregnated dog collars on incidence of zoonotic visceral leishmaniasis in Iranian children: a matched- cluster randomised trial. Lancet 2002; 360(9330): 374-379. http://dx.doi.org/10.1016/ S0140-6736(02)09609-5. PMid:12241778.

Gontijo CMF, Melo MN. Leishmaniose visceral no Brasil: quadro atual, desafios e perspectivas. Rev Bras Epidemiol 2004; 7(3): 338-349. http://dx.doi.org/10.1590/S1415-790X2004000300011.

Ikeda-Garcia FA, Ciarlini PC, Feitosa MM, Gonçalves ME, Luvizotto MCR, Lima VMF. Perfil hematológico de cães naturalmente infectados por Leishmania chagasi no município de Araçatuba, São Paulo: estudo retrospectivo de 191 casos. Rev Clin Vet 2003; 47: 42-48.

Inokuma H, Ohno K, Onishi T, Raoult D, Brouqui P. Detection of Ehrlichial infection by PCR in dogs from Yamaguchi and Okinawa Prefectures, Japan. J Vet Med Sci 2001; 63(7): 815-817. http://dx.doi.org/10.1292/jvms.63.815. PMid:11503912.

Jain NC. Hematologic Techniques. In: Jain NC, editor. Schalm's Veterinary Hematology. Philadelphia: Lea \& Febiger; 1986. p. 20-86.

Leal GGA, Carneiro M, Pinheiro AC, Marques LA, Ker HG, Reis AB, et al. Risk profile for Leishmania infection in dogs coming from an area of visceral leishmaniasis reemergence. Prev Vet Med 2018; 150: 1-7. http://dx.doi.org/10.1016/j.prevetmed.2017.11.022. PMid:29406075.

Leite BMM, Solcà MS, Santos LCS, Coelho LB, Amorim LDAF, Donato LE, et al. The mass use of deltamethrin collars to control and prevent canine visceral leishmaniasis: a field effectiveness study in a highly endemic area. PLoS Negl Trop Dis 2018; 12(5): e0006496. http://dx.doi.org/10.1371/journal.pntd.0006496. PMid:29758031.

Liddell S, Jenkins MC, Dubey JP. A competitive PCR assay for quantitative detection of Neospora caninum. Int J Parasitol 1999; 29(10): 1583-1587. http://dx.doi.org/10.1016/S0020-7519(99)00101-0. PMid:10608445.

Lima VMF, Gonçalves ME, Ikeda FA, Luvizotto MCR, Feitosa MM. Anti-leishmania antibodies in cerebrospinal fluid from dogs with visceral leishmaniasis. Braz J Med Biol Res 2003; 36(4): 485-489. http://dx.doi.org/10.1590/S0100-879X2003000400010. PMid:12700826.

Lobo KS, Bezerra JM, Brito LM, da Silva JS, Pinheiro VC. Conhecimentos de estudantes sobre Leishmaniose Visceral em escolas públicas de Caxias, Maranhão, Brasil. Cien Saude Colet 2013; 18(8): 2295-2300. http://dx.doi.org/10.1590/S141381232013000800013 . PMid:23896911.

Lopes EG, Sevá AP, Ferreira F, Nunes CM, Keid LB, Hiramoto RM, et al. Serological and molecular diagnostic tests for canine visceral leishmaniasis in Brazilian endemic area: one out of five seronegative dogs are infected. Epidemiol Infect 2017; 145(12): 2436-2444. http://dx.doi.org/10.1017/S0950268817001443. PMid:28726597.

Marcondes M, Rossi CN. Leishmaniose visceral no Brasil. Braz J Vet Res Anim Sci 2014; 50(5): 341-352. http://dx.doi.org/10.11606/ issn.2318-3659.v50i5p341-352.

Matos HJ, Pinto AYN, Miranda AMM, Silva FLC, Ramos FLP. Reação cruzada nos testes sorológicos entre doença de Chagas e leishmaniose visceral em regiões endêmicas para ambas as doenças. Rev Pan-Amaz Saúde 2015; 6(1): 65-68. http://dx.doi. org/10.5123/S2176-62232015000100007.

Mendes RS, Santana VL, Jansen AM, Xavier SCC, Vidal IF, Rotondano TEF, et al. Aspectos epidemiológicos da Doença de Chagas canina no semiárido paraibano. Pesq Vet Bras 2013; 33(12): 1459-1465. http://dx.doi.org/10.1590/S0100-736X2013001200011.

Menezes JA, Luz TCB, Sousa FF, Verne RN, Lima FP, Margonari C. Fatores de risco peridomiciliares e conhecimento sobre leishmaniose visceral da população de Formiga, Minas Gerais. Rev Bras Epidemiol 2016; 19(2): 362-374. http://dx.doi. org/10.1590/1980-5497201600020013. PMid:27532759.

Morais MHF, Fiuza VOP, Araújo VEM, Menezes FC, Carneiro M. Avaliação das atividades de controle da leishmaniose visceral em Belo Horizonte, Minas Gerais, 2006-2011. Epidemiol Serv Saude 2015; 24(3): 485-496. http://dx.doi.org/10.5123/S167949742015000300014.

Nakaghi ACH, Machado RZ, Costa MT, André MR, Baldani CD. Canine ehrlichiosis: clinical, hematological, serological and molecular aspects. Cienc Rural 2008; 38(3): 766-770. http://dx.doi.org/10.1590/S0103-84782008000300027. 
Oliveira PL, Souza SL, Bonatto NCM, Silva NLT, Mancebo AM, Bosculo MRM, et al. Effect of food intake on complete blood count of healthy dogs. Rev Agr Acad 2020; 3(6): 105-116. http://dx.doi.org/10.32406/v3n62020/105-116/agrariacad.

Peters IR, Peeters D, Helps CR, Day MJ. Development and application of multiple internal reference (housekeeper) gene assays for accurate normalisation of canine gene expression studies. Vet Immunol Immunopathol 2007; 117(1-2): 55-66. http://dx.doi. org/10.1016/j.vetimm.2007.01.011. PMid:17346803.

Prado PF, Rocha MF, Sousa JF, Caldeira DI, Paz GF, Dias ES. Epidemiological aspects of human and canine visceral leishmaniasis in Montes Claros, State of Minas Gerais, Brazil, between 2007 and 2009. Rev Soc Bras Med Trop 2011; 44(5): 561-566. http://dx.doi. org/10.1590/S0037-86822011000500006. PMid:22031070.

Queiroz NMGP, Assis J, Oliveira TMFS, Machado RZ, Nunes CM, Starke-Buzetti WA. Diagnóstico da Leishmaniose Visceral Canina pelas técnicas de imunoistoquímica e PCR em tecidos cutâneos em associaçaão com a RIFI e ELISA-teste. Rev Bras Parasitol Vet 2010; 19(1): 32-38. http://dx.doi.org/10.4322/rbpv.01901006. PMid:20385057.

Rangel O, de Oliveira SS, Hiramoto RM, Henriques LF, Viviani A Jr, Taniguchi HH, et al. Epidemiological classification of the municipalities of the State of São Paulo according to the Visceral Leishmaniasis Control and Surveillance Program, 2019. BEPA 2020; 17(204): 13-34.

Sevá AP, Ovallos FG, Amaku M, Carrillo E, Moreno J, Galati EAB, et al. Canine-Based Strategies for Prevention and Control of Visceral Leishmaniasis in Brazil. PLoS One 2016; 11(7): e0160058. http://dx.doi.org/10.1371/journal.pone.0160058. PMid:27471852.

Sousa MVC. Influence factories the sensitivity parasitological diagnosis of canine leishmaniasis visceral. [dissertação]. Uberlândia: Universidade Federal de Uberlândia; 2012.

Spalding SM, Amendoeira MRR, Coelho JMC, Angel SO. Otimização da reação de polimerase em cadeia para detecção de Toxoplasma gondii em sangue venoso e placenta de gestantes.J Bras Patol Med Lab 2002; 38(2): 105-110. http://dx.doi.org/10.1590/ S1676-24442002000200006.

Spolidorio MG, Labruna MB, Zago AM, Donatele DM, Caliari KM, Yoshinari NH. Hepatozoon canis infecting dogs in the State of Espírito Santo, southeastern Brazil. Vet Parasitol 2009; 163(4): 357-361. http://dx.doi.org/10.1016/j.vetpar.2009.05.002. PMid:19482427.

Spolidorio MG, Torres MM, Campos WNS, Melo ALT, Igarashi M, Amude AM, et al. Molecular detection of Hepatozoon canis and Babesia canis vogeli in domestic dogs from Cuiabá, Brazil. Rev Bras Parasitol Vet 2011; 20(3): 253-255. http://dx.doi.org/10.1590/ S1984-29612011000300015. PMid:21961759.

Vaz TP, Gama-Melo MO, Quaresma PF, Gontijo CMF, Santos G, Barbosa FS, et al. Evaluation of the euthanasia of seropositive dogs for canine visceral leishmaniasis as the only method of controling the disease in the enzootic area in the Midwestern Minas Gerais. Pesq Vet Bras 2020; 40(2): 107-112. http://dx.doi.org/10.1590/1678-5150-pvb-6165.

Ventura RM, Takeda GF, Silva RAM, Nunes VLB, Buck GA, Teixeira MMG. Genetic relatedness among Trypanosoma evansi stocks by random amplification of polymorphic DNA and evaluation of a synapomorphic DNA fragment for species-specific diagnosis. Int J Parasitol 2002; 32(1): 53-63. http://dx.doi.org/10.1016/S0020-7519(01)00314-9. PMid:11796122.

World Health Organization - WHO. Leishmaniais [online]. Geneva: WHO; 2016 [cited 2021 Fev 17]. Available from: http://apps. who.int/neglected_diseases/ntddata/leishmaniasis/leishmaniasis.html

Zanette MF, Lima VMF, Laurenti MD, Rossi CN, Vides JP, Vieira RFC, et al. Serological cross-reactivity of Trypanosoma cruzi, Ehrlichia canis, Toxoplasma gondii, Neospora caninum and Babesia canis to Leishmania infantum chagasi tests in dogs. Rev Soc Bras Med Trop 2014; 47(1): 105-107. http://dx.doi.org/10.1590/0037-8682-1723-2013. PMid:24603745. 